\title{
Determinants of Private Giving to Public Colleges and Universities
}

Received (in revised form): February 1, 2006

\section{Ying Liu}

Ying Liu is a doctoral student studying Higher Education Leadership and Policy in Vanderbilt University's Peabody College.

\begin{abstract}
This paper explores the relationship between institutional factors, policy and governance factors, and macroeconomic factors and variations in overall voluntary support and its varying sources to public colleges and universities. Study results suggest that institutions at the top of the institutional hierarchy enjoy accumulative advantage in generating voluntary support; that increased tuition level has a negative effect on corporate, foundation, and total private giving; and that different donor groups have different motivations for making gifts.

International Journal of Educational Advancement (2006) 6, 119-140. doi:10.1057/palgrave.ijea.2150014
\end{abstract}

Keywords:

fund raising, public higher education, accumulative advantage

\footnotetext{
Author's Contact Address:

Ying Liu

Doctoral Student.

Higher Education Leadership and Policy Program

Vanderbilt University's Peabody College

Box 514 - GPC, 230 Appleton Place Nashville,

TN 37203, USA.

Email: ying.liu@vanderbilt.edu

Phone: 615-460-9932

Fax: 615-343-7094
}

\section{Context}

In recent years, increasing market competitiveness and rising educational costs have underscored the importance of external revenues in higher education finance. Even as the growth in higher education costs continues to exceed the rate of inflation, the proportions of public funding from both state and federal sources are steadily declining. As traditional funding sources become less reliable, colleges and universities seek to diversify their revenue streams.

While in the past private giving has been used as supplemental funding in higher education institutions, voluntary support ${ }^{1}$ of higher education institutions in recent years has become increasingly important to sustaining operating budgets. As Johnstone (2002) pointed out, private giving is "a potentially important source of nongovernmental, or third stream, revenue" (p. 33). For most institutions, competing successfully for private giving provides not only additional resources that aid the institutions in fulfilling their mission but also the means to ensure "margin of excellence" in areas such as academic programs, research initiatives, faculty and student support, and facilities (Leslie et al., 1983). For public and 
private universities alike, it gives institutions more flexibility in planning and decision making and is the only financial resource with potential for significant growth (Johnstone, 2002). Furthermore, the act of seeking funds and then providing ongoing stewardship strengthens bonds between universities, their alumni and their communities, and increases accountability and responsiveness. In 2003-04, total voluntary support for higher education was $\$ 24.4$ billion, with 56 percent earmarked for current operations and the remainder for capital purposes (National Center for Education Statistics 2005) Most of this support came from alumni (27 percent), nonalumni individuals ( 21 percent), corporations (18 percent), foundations (25 percent), religious organizations (1 percent), and other organizations (6 percent) (National Center for Education Statistics, 2005).

Once considered the preserve of independent colleges, fund raising in public higher education has become accepted by both donors and colleges. In the early years, fund raising was based more heavily on charity and was concentrated in private institutions (Brittingham and Pezzullo, 1990). Public institutions were seen as having the support of the state and therefore as ineligible for private support, or the institutions themselves saw it as unnecessary. However, in recent years, state support to public higher education has been diminishing. According to data from the National Center of Educational Statistics, the share of governmental funding in institutional revenue of public degreegranting institutions has declined from 45.6 to 35.6 percent from $1980-81$ to 2000-01. To make up for the lost funding from state and federal government and to maintain academic quality in the face of financial constraints, American public colleges and universities have raised their tuition and fees rapidly and also have aggressively pursued revenues from private sources (Hearn, 2003; Johnstone, 2002). Once considered optional or a fringe activity, voluntary support has become increasingly important to public institutions. Seeing private giving as an alternative source of revenue, many public colleges and universities have borrowed the techniques and methods from the private institutions to pursue it and developed programs to increase the amount of voluntary support that the institutions receive. In the same period, the share of tuition and fees has increased from 12.9 to 18.1 percent, and the share of private gifts, grants, and contracts from 2.9 to 5.1 percent. Still, compared with private institutions, most public colleges and universities relatively lack experience in fund raising. University developmental professionals must be able to position their institutions favorably with funding sources so that they can maximize their private giving.

\section{Problem}

Despite the general importance of private giving to public colleges and universities, it remains to be further explored in academic research. Empirical investigations in private giving to higher education have increased in recent years, but most research on fund raising in higher education has primarily focused on the following major areas: motivational studies of donors and case studies of fund raising in higher education 
institutions with varied characteristics. Only a few studies examine which factors influence voluntary support for public institutions of higher education. Given the apparent importance of voluntary support to higher education in the near future, there is a need to know more about the association of certain factors with the levels, sources, and centrality of private giving in institutions. That improved knowledge should not only help public higher education institutions improve their financial prospects but also contribute to analytic understanding of the dynamics of institutional financial management.

\section{Purpose and Research Questions}

The purpose of this paper is to investigate the role of institutional factors, policy and governance factors, and macroeconomic factors in explaining variations in overall voluntary support and its varying sources to public colleges and universities. There are four primary groups of donors providing voluntary support in higher education: alumni, nonalumni individuals, corporations, and foundations. Each group of donors has different motivations for giving and each has a tendency to designate gifts differently. Also, previous research suggests that certain institutional traits are more effective in increasing the probability and amount of support from certain types of donors, and certain selected policy and governance factors as well as economic factors account for variations in levels of voluntary support to colleges and universities (i.e., Leslie et al., 1983; Leslie and Ramey, 1988).
This study addresses the following specific research questions:

1. Which institutional, policy and governance, and macroeconomic factors are most closely associated with the generation of voluntary support in public postsecondary institutions?

2. How do these factors differently influence the four sources of private givingalumni, nonalumni individuals, corporations, and foundations?

\section{Previous Research on Private Giving to Higher Education}

There is a rather large economic literature that considers both theoretically and empirically the impact of tax deductions on the quantity of overall charitable contributions (see Taussig, 1967; Feldstein, 1975a, b; Clotfelter, 1985). Most of the literature generally found that tax deductibility has a positive and statistically significant relationship with charitable giving.

A small body of research focusing specifically on charitable contributions to higher education has empirically examined the determinants of donative revenue flows. In general, these studies have found that total voluntary support to higher education institutions has been related to the size of a college's endowment (Dunn et al., 1988; Duronio et al., 1988a, b; Leslie and Ramey, 1988; Pickett, 1977), the level of educational and general expenditures (Dunn et al., 1988; Duronio et al., 1988a, b; Leslie and Ramey, 1988), FTE enrollment (Coughlin and Erekson, 1986; Duronio 
et al., 1988a, b; Leslie and Ramey, 1988), the number of alumni of record (Duronio et al., 1988a, b; Pickett, 1977), the type of institutional governance (Drachman, 1983), Gourman quality rating (Drachman, 1983; Leslie and Ramey, 1988), the level of fund-raising expenditures (Duronio et al., 1988a, b; Pickett, 1977), and the size of the fund-raising staff (Pickett, 1977; Woods, 1987).

In her CASE Grenzebach awardwinning dissertation, Woods (1987) attempted to identify the institutional characteristics and fund-raising practices that were most closely associated with an institution's gift income by using a sample of 77 public research/doctoral universities. Her analysis incorporated the following variables: financial resources (number of alumni, federally sponsored research grants, legislative appropriations, and student aid funds), inherent institutional characteristics (age, endowment, in-state and total enrollment, cost of attendance, E\&G expenditures, number of advancement professional staff), organizational components (fund-raising and constituent relations goals, planning, staffing, budget, experience, and structure), method components (solicitation techniques, written proposal, capital campaign, and use of trustees, faculty, president, students, volunteers), gift emphasis components (annual, deferred, corporate, foundation, and major giving emphasis), and US regional locations. She identified financial resources and inherent institutional characteristics as two factors especially crucial to success in fund raising.

While most previous studies address private giving to higher education as a function of contemporaneous institutional characteristics, Cochi Ficano and Cunningham (2001) contributed to the literature by including a 13-year lag between measures of the determinants of alumni giving and average donation per alumnus. Utilizing a sample of 415 public and private higher education institutions, they explored the role that lagged institutional characteristics and policy have on subsequent alumni donations to the institutions. Their results demonstrated the noncontemporaneous effects of variations of institutional characteristics such as academic reputation and student-faculty ratio on subsequent flows of alumni giving. Both mean Scholastic Assessment Test and self-reporting entrance difficulty were positive and statistically significant, and mean SAT was the most economically meaningful stimulant to average alumni donations. In addition, "a standard deviation increase in the faculty-student ratio (two additional faculty per one hundred students) is associated with a $\$ 17$ increase in contributions per alumnus or $\$ 442,000$ from all alumni annually" (p. 559).

Although most studies on voluntary support to higher education focus on attributes of institutions, a few researchers incorporated macroeconomic factors in their analysis of fund raising in higher education and provided empirical evidence (Coughlin and Erekson, 1986; Drachman, 1983; Leslie et al., 1983; Leslie and Ramey, 1988; Smith and Ehrenberg, 2003; Gianneschi, 2004).

Using time-series regression analysis on data from 1932 to 1974 , Leslie et al. (1983) examined the impact over 
time of economic factors and federal tax policies on overall voluntary support for higher education. Their results showed that aggregate voluntary support to higher education was significantly affected by changes in economic variables that reflect the level of economic activities, corporate profits, and personal savings. Leslie et al. (1983) found the most powerful (and positive) predictor of giving to higher education was Standard and Poor's 500 measure of the equities market, followed by bond yields, and consumer prices. By examining the impact of selected economic factors on the share of total contributions to higher education by business over time, Leslie et al. (1983) found that contrary to individual giving, corporate giving expanded with bullish economic conditions and inflation, but declined with government intervention (taxation). By examining the impact of selected economic factors on the share of total contributions to higher education by individuals over time, Leslie et al. (1983) found that individuals perceive greater institutional needs when economic conditions are relatively poor and would give more during such times. Individual giving was found to increase when stock equities, inflation, and bond yields were down and tax collections were up.

Subsequent studies used the disaggregated level of analysis by examining the determinants of voluntary contribution to individual colleges and universities. Using data of 52 universities for 1980-81 via ordinary lease-squares estimation, Coughlin and Erekson (1986) examined the determinants of voluntary contribution to institutions of higher education in five different categories, namely, total voluntary support, support for current operations, support for capital operations, corporate support, and alumni support. Athletic success was a significant determinant of total voluntary support, total support for current operations, and total support for capital operations, and SAT and student enrollment were significantly positively related to total voluntary support and total support for current operations. Per-capita income did not perform as expected as consistent with earlier work (i.e., Leslie et al., 1983) and was found to significantly affect only total capital giving. Coughlin and Erekson (1986) found that corporate giving was significantly affected by institutional quality and size. This finding was consistent with the authors' hypothesis that corporations are more interested in supporting an improved future labor force and tend to concentrate their giving disproportionately in large institutions where their giving would have broader impact. Alumni giving was significantly affected by Gourman's ranking of public relations programs and athletic success.

In their widely cited study using data from 73 major research universities for the years 1977 and 1980, Leslie and Ramey (1988) found that the effects of size, expenditures per student, endowment per alumnus, and regional growth (as measured by per-capita income, state dividend and interest income, and the percentage of federal income tax returns itemized in a state) on total voluntary support are significantly positive, whereas the Gourman rating, age, and state appropriations are insignificant. 
Surprisingly, current effort to enhance donor-institution relationships, as reflected by the percent of alumni of record solicited, has a small negative effect on total voluntary support. The authors therefore concluded that the long-term donor-institution relationships appear to have a larger role in explaining total voluntary support. Leslie and Ramey (1988) composed separate models for the various donor groupsalumni, nonalumni individuals, business corporations, and nonbusiness organizations-and tried to infer the logic of donor behavior from institutional and regional characteristics and from institutional actions. Their study suggested that most donors like to give to thriving institutions that already are targets of public philanthropy, although alumni also respond to a perception of institutional need. Institutional quality as reflected in expenditures per student and past fund-raising success as reflected in endowment per alumnus are of significance to nonalumni donors, but not alumni donors. Institutional prestige as represented by both the Gourman rating and age values is the main predictor of alumni contribution. State appropriation per student has a statistically significant negative influence on both alumni and nonalumni donors, with elasticities of -0.34 for alumni and -0.43 for nonalumni. This suggested that "individuals respond most favourably in times of institutional need, when economic conditions are poor" (p. 118). The percent of alumni solicited does not significantly affect individual contributions, which indicated that "current efforts to add to the stock of useful philanthropic relationships have little immediate effect on individuals" (p. 127).

Using data from a panel of private research universities from the 1968-69 to 1998-99 period, Smith and Ehrenberg (2003) built a structural model of the sources and uses of giving with both characteristics of the institutions and macroeconomic variables. Smith and Ehrenberg (2003) found that an increase in the estate tax rate, holding other influences constant, led to an increase in the share of foundation giving and a corresponding decrease in the share of corporate giving and that higher capital gains tax rates were associated with lower levels of giving from alumni and other individuals. Institutions at the top tier of US News \& World Report ranking obtained the highest alumni, foundation, and corporate giving. They also reported that "larger institutions, as measured by enrollment levels, and wealthier institutions, as measured by endowment per student, also received higher levels of giving from all sources" (p. 74). Lastly, a larger number of alumni per enrolled student is related to a higher level of alumni giving but a lower level of other individual giving.

Using financial data from a nationally representative sample of 161 public colleges and universities, Gianneschi (2004) examined whether changes in state appropriations are related to changes in voluntary support using ordinary least-squares regression and fixed effects regression. Ordinary least-squares technique revealed that corporations and other individuals were more likely to give to an institution when it receives higher levels of state appropriations and that voluntary support from alumni and 
foundation was not related to state appropriations. A positive relationship was found between state appropriations and restricted giving levels from corporations and other individuals and no relationship was found between unrestricted giving levels and state appropriations. Controlling for all institutional and state fixed (time-invariant) characteristics, fixed effects regression techniques were used to test the relationships between voluntary support and state appropriations and regional economic indicators. The results showed that state appropriations were consistently, positively, and significantly related to total voluntary support and total restricted voluntary support, and for restricted voluntary support from each donor group.

In sum, scholarly research on private giving to higher education is very limited and has had a very short history as a serious subject of study. Few of the papers did time-series analysis on the determinants of private giving to individual colleges and universities. The samples used in most past work were limited to a set of major research universities (e.g., Leslie and Ramey, 1988; Smith and

Ehrenberg, 2003; Woods, 1987). That research universities are not representative of all colleges and universities in the United States makes it difficult to generalize the results to other types of institutions. Therefore, the results of these studies should be interpreted with caution and the analysis should be replicated with a wider variety of colleges and universities. On the other hand, the results do encourage future researchers to study whether institutional type exerts some influence on voluntary support to an institution. Another flaw of several past studies is the use of Gourman rating as a proxy for academic quality (e.g., Coughlin and Erekson, 1986; Leslie and Ramey, 1988). The Gourman Report, from which the rating in Leslie and Ramey's study is obtained, was widely criticized for its methodology and for its noticeably skewed rankings in favor of large state universities (Selingo, 1997).

The reviewed literature showed that there are significant differences in the determinants of support among various categories of support, and while some results of different studies are consistent, others contradicted each other. For example, although using different measures of institutional quality, both Gianneschi (2004) and Smith and Ehrenberg (2003) found that alumini, corporation, and foundation givings are positively related to institutional quality. Contrary to Leslie and Ramey's (1988) finding that alumni and nonalumni increase giving when state appropriation declines, Gianneschi (2004) found no significant relationship between state appropriation and alumni giving but a significant positive relationship between state appropriation and nonalumi giving. This calls for further exploration on private giving to higher education.

\section{Conceptual Framework}

The conceptual framework for this study draws on social exchange theory, organizational theories, and previous research on the determinants of voluntary support to higher education institutions. 
Exchange theory has been used by researchers to explain donor behaviors in the higher education context (e.g., Hale, 1987). Kelly (1991) stated, "Fund raising predominantly involves a social exchange relationship between a charitable organization and a donor, in which the power of each relative to the other determines the outcome of the exchange" (p. 199). A business transaction is typically considered an exchange of money for a product or service. However, in the case of nonprofit organizations such as higher education institutions, the benefits of philanthropic exchanges are both economic ("tax incentives, goods and services, exclusive favors, and gifts") and social ("group membership, status and prestige, avoidance of peer sanctions, and friendship") (Hale, 1987 , p. 202). This type of transaction can be defined as an exchange of values between two parties (Kotler, 1972). I posit that the relationships between donors and higher education institutions are based on social exchange. As Blau (1968) pointed out, the "most important benefits involved in social exchange do not have any material value on which an exact price can be put at all, as exemplified by social approval and respect" (p. 455). In higher education fund raising, social benefits to donors play a primary role, and higher education institutions often rely heavily on the promise of social benefits from their products. Therefore, it is important that higher education institutions acquire a better understanding of the factors affecting relationships that involve primarily social exchange.

Donors of different types may expect different benefits from their gifts and therefore may have different motivations to donate. Alumni and other individual donors are likely to be motivated by institutional pride, prestige, and emotional attachment, or they may give because they want to ensure the marketability of their degree and their children's degree earned from an institution. Nonalumni and foundations are more interested in quality and social/educational benefit. Nonalumni individuals may be motivated to donate by a desire to give something back to society. Foundations are more interested in the prestige of a college and may give to enable an institution to produce better-quality higher education for society (Brittingham and Pezzullo, 1990). Corporations often give to receive some type of benefit in return for their investment, and tend to donate money to institutions with which they want to cultivate relationships. For example, companies may make a gift to facilitate applied research at an institution that might benefit their business, or they may donate money to support higher education for the improvement of the local community in the hopes of building social and human capital of the region (Brittingham and Pezzullo, 1990; Coughlin and Erekson, 1986; Brewer, Gates, and Goldman, 2001). In this study, voluntary support by four major donor groups-alumni, nonalumni individuals, corporations, and foundations-will be analyzed as dependent variables individually.

Research demonstrates that private giving is a complex process, subject to the influences of two types of intervening variables or forces: institutional and environmental. From the review of literature on fund 
raising, three types of institutional factors that are related to the success of an institution's fund-raising program emerge: capacity, history, and effort (Brittingham and Pezzullo, 1990).

An institution's capacity may be thought of as the hypothetical maximum private support an institution could raise under the best conditions. Capacity for fund raising is partly a function of the size of a college's alumni and the collective wealth of its alumni, and the increase of the size of an institution's alumni body determines its potential for attracting donations (Woods, 1987). Since the increase in size of alumni might encourage development offices to devote more resources to making connections to alumni rather than other groups of donors, it is hypothesized that:

\section{$\mathrm{H}_{1 \mathrm{a}}$ : Increase in alumni size will lead to higher alumni giving and higher total private giving.}

$\mathrm{H}_{1 \mathrm{~b}}$ : Increase in alumni size will lead to lower private giving from nonalumni, corporations, and foundations.

Capacity may also refer to the institution's total resources such as institutional quality and institutional wealth. Quality is a fundamental part of the fund-raising mix. Donors expect institutions to convey a commitment to maintain quality or a commitment to achieve quality (Cook and Lasher, 1996). Donors who have never attended a particular institution will have less confidence in their ability to evaluate whether the institution is making appropriate resource allocation decisions and therefore may look to an institution's quality as a proxy. The assumption that donors pursue social benefits in providing financial support in higher education institutions also leads to the prediction that institutions of greater institutional quality receive higher private giving from different types of donors who intend to increase educational benefits to society and thus maximize their own well being. In addition, according to accumulative advantage, wealthier institutions tend to raise more money than less wealthier ones (Caboni, 2003; Pickett, 1977; Woods, 1987). The hypotheses of institutional quality and wealth are as follows:

$\mathrm{H}_{2}$ : Institutions of greater institutional quality will receive higher private giving from all four types of donors and higher total private giving.

$\mathrm{H}_{3}$ : Institutions of greater institutional wealth will receive higher private giving from all four types of donors and higher total private giving.

A substantial history in fund raising not only provides an opportunity for programs to mature but also builds a sense of expectation or tradition in fund raising. Endowment per FTE is used as a proxy of fund-raising history. The hypothesis of fund-raising history is:

$\mathrm{H}_{4}$ : Increase in endowment per FTE leads to higher private giving from all four types of donors and higher total private giving.

The effort or priority an institution gives its fund-raising program is also 
generally related to fund-raising success. The hypothesis is as follows:

$\mathrm{H}_{5}$ : Increase in fund-raising effort will lead to higher private giving from all four types of donors and higher total private giving.

Contemporary organization theories focus on the external environment as a crucial influence on the structures and activities of an organization. For environmental factors, the author includes policy and governance factors such as level of state financial and personnel flexibility and state support to higher education and macroeconomic factors (Clotfelter, 1985; Leslie et al., 1983).

The amount of regulation and control by state government affects how universities make strategic choices in financial management. In several seminal empirical studies conducted by Volkwein (1984, 1986a, 1986b, 1987, 1989), it was found that institutions that are less hampered by state fiscal control are less dependent on state appropriations and raise a larger portion of their funds from nonstate sources. One possible explanation offered by Volkwein $(1984,1986 a)$ is that freedom from state academic and financial constraints may encourage universities to shift administrative resources away from coping with state bureaucracy and into more costeffective activities such as fund raising. Since higher education generates significant benefits to society as a whole, state governments provide their support to public colleges and universities through allocation of tax revenues. Prior studies have found relatively crowding-out effects of government funding on private contributions to nonprofit organizations (Steinberg, 1993; Kingma, 1989). Because part of any donor's income is already allocated to these institutions via tax levies, government funding at low levels may stimulate private giving to higher education, and at high levels it could have the opposite effect (Brooks, 1999; Leslie and Ramey, 1988). From previous research on the influence of state regulation and state financial support to higher education, two hypotheses are developed as follows:

$\mathbf{H}_{6}$ : Institutions with a high level of state financial and personnel flexibility will get more from fund raising than those with a low or medium level of state financial and personnel flexibility.

$\mathrm{H}_{7}$ : Increase in state support to higher education will lead to lower private giving from all four types of donors and higher total private giving.

Private giving appears to closely follow economic trends in general. Given the differences in motivations of different donor groups, it is reasonable to expect that corporations tend to donate less in times of economic downturn, while individuals seem unaffected by fluctuations in the economy and are more likely to respond to particular needs of an institution when making contribution decisions. The hypothesis is formulated as:

$\mathrm{H}_{8}$ : State economic growth will lead to higher total private giving and higher giving from corporations and foundations, but not from alumni and nonalumni individuals. 
The present study represents an initial step in establishing a conceptual framework for explaining private giving to pubic higher education institutions, which requires moving beyond the perceptions of individual donors and grant-seekers to an aggregate analysis of contributions. It is important because a clear understanding of the forces influencing voluntary support has major implications for fund-raisers at public colleges and universities. Once we know about what appeals to alumni, nonalumni individuals, foundations, and corporations, we can develop more effective fund-raising plans targeting the needs of different donors (Figure 1).

\section{Research Design}

\section{Data}

Data used in the study were assembled from several sources. Information on voluntary support by source is provided by the Voluntary Support to Education (VSE) survey developed by the Council for Aid to Education. Data on tuition, total revenue, and state appropriation for each institution were taken from Integrated Postsecondary Education Data System (IPEDS). Information on state tax fund appropriation for higher education per $\$ 1000$ of state personal income was taken from state tax fund appropriations for higher education FY1961-FY2005 as provided by the website www.postsecondary.org. Data on state per-capita income were from the Bureau of Economic Analysis. The classification of administrative flexibility of state universities constructed by Volkwein and Malik (1997) was used for the measure of the level of state control of institutional budget.

Information on medical schools was

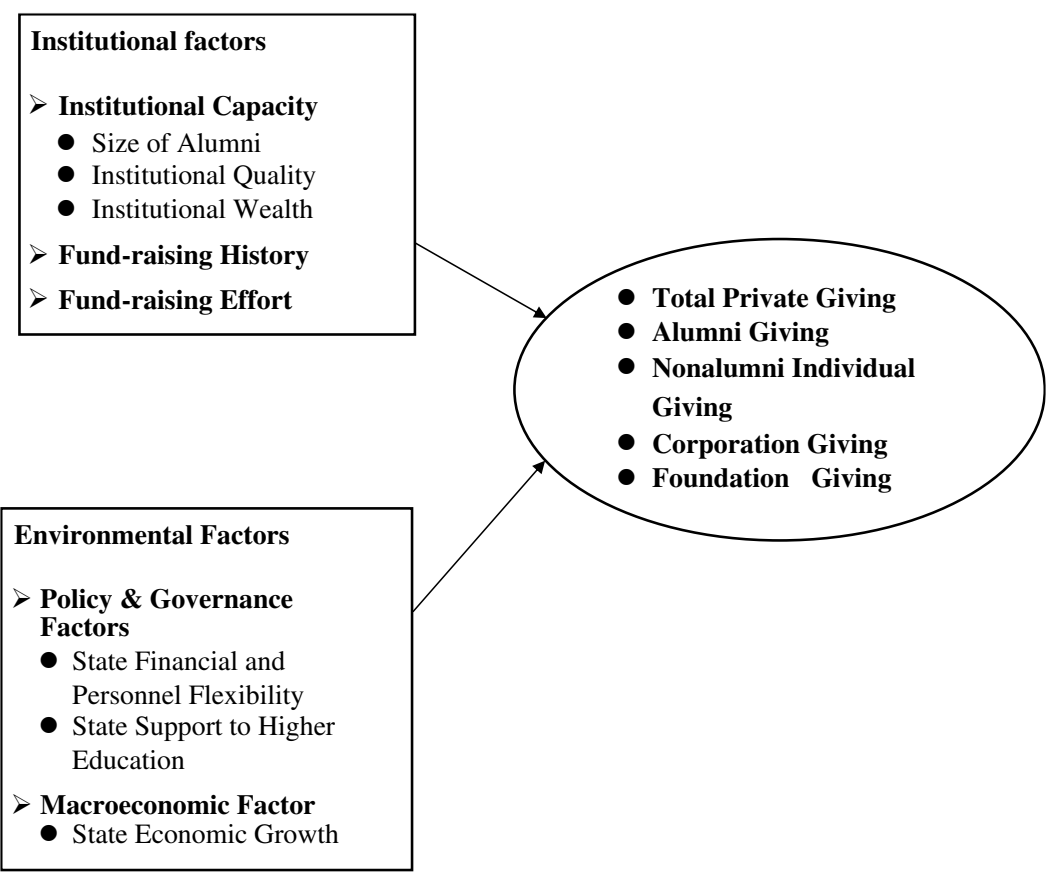

Figure 1: Conceptual framework of the study 
taken from Graduate Medical Education Directory 2004-05. Data in dollar terms were adjusted to constant 1983 dollars using the Higher Education Price Index.

\section{The variables}

Total private giving in 2002-03 from all sources and total private giving as a proportion of total revenue were used as the primary dependent variables. Four submodels were also analyzed, using as dependent variables the voluntary giving of alumni, nonalumni, corporations, and foundations, respectively, to each institution in the study. This breakdown was used because past literature has recognized that there are significant motivational differences between alumni and donors of other groups (Coughlin and Erekson, 1986; Leslie et al., 1983; 1988 Leslie and Ramey, 1988).

To capture the lagged effects of the variables on giving, all institutional variables, with the exception of Carnegie Classification, are measured in the year 1995. This introduces at least an 8-year lag between the majority of the explanatory variables and the data used to construct dependent variables, thereby reducing the effects of contemporaneous reverse causation on the results. To examine how changes in some institutional, political, and macroeconomic factors over time affect the dependent variables, the change of these independent variables over the period from 1995 to 2003 was used.

Five clusters of independent variables, institutional capacity, fund-raising history, fund-raising effort, policy and governance factors, and macroeconomic factor, are discussed as follows.
Full-time-equivalent enrollment of 1995 was included to control for the size of the institution. Regarding the presence of medical school, a dummy variable was employed: 1 if the university has a medical school, 0 otherwise. To operationalize institutional type, the widely used Carnegie Classification in 1994 was employed. In voluntary support of education, doctoral/research universities I and doctoral/research universities II were collapsed into a single category, master's colleges and universities I and II were collapsed into a single category, and baccalaureate colleges-liberal arts and baccalaureate colleges-general were collapsed into a single category. For the purpose of study, this categorization was followed, and a dummy variable representing research/doctoral universities was used in the models. Change of number of alumni of record was used to measure the change of size of alumni.

Institutional quality was measured through US News and World Report ranking for national universities and change of expenditure per FTE. For the purpose of analysis, national universities in quartiles 1 and 2 were collapsed into a single category, and a dummy variable representing quartiles 1 and 2 was used in the models. Change of expenditure per FTE was used to reflect an institution's commitment to educational quality, independent of institutional prestige consideration. To reflect institutional wealth, in-state tuition and total revenue were used. In addition, change of endowment per FTE is used as an indicator of an institution's fund-raising history, and change in the percentage of alumni solicited is used as an 
indi-cator of an institution's fundraising efforts.

Change of state appropriation per FTE, level of state financial and personnel flexibility, and state tax effort for higher education are used as indicators of policy and governance factors. Two dummy variables representing a high level of state financial and personnel flexibility and a medium level of state financial and personnel flexibility were used, and a low level of state financial and personnel flexibility was used as the omitted variable. Change of state tax fund appropriation for higher education per $\$ 1,000$ of state personal income was used as an indicator of state tax support for higher education. Turning to macroeconomic environment, change of state per-capita income was used as a measure of regional economic growth (Figure 2).

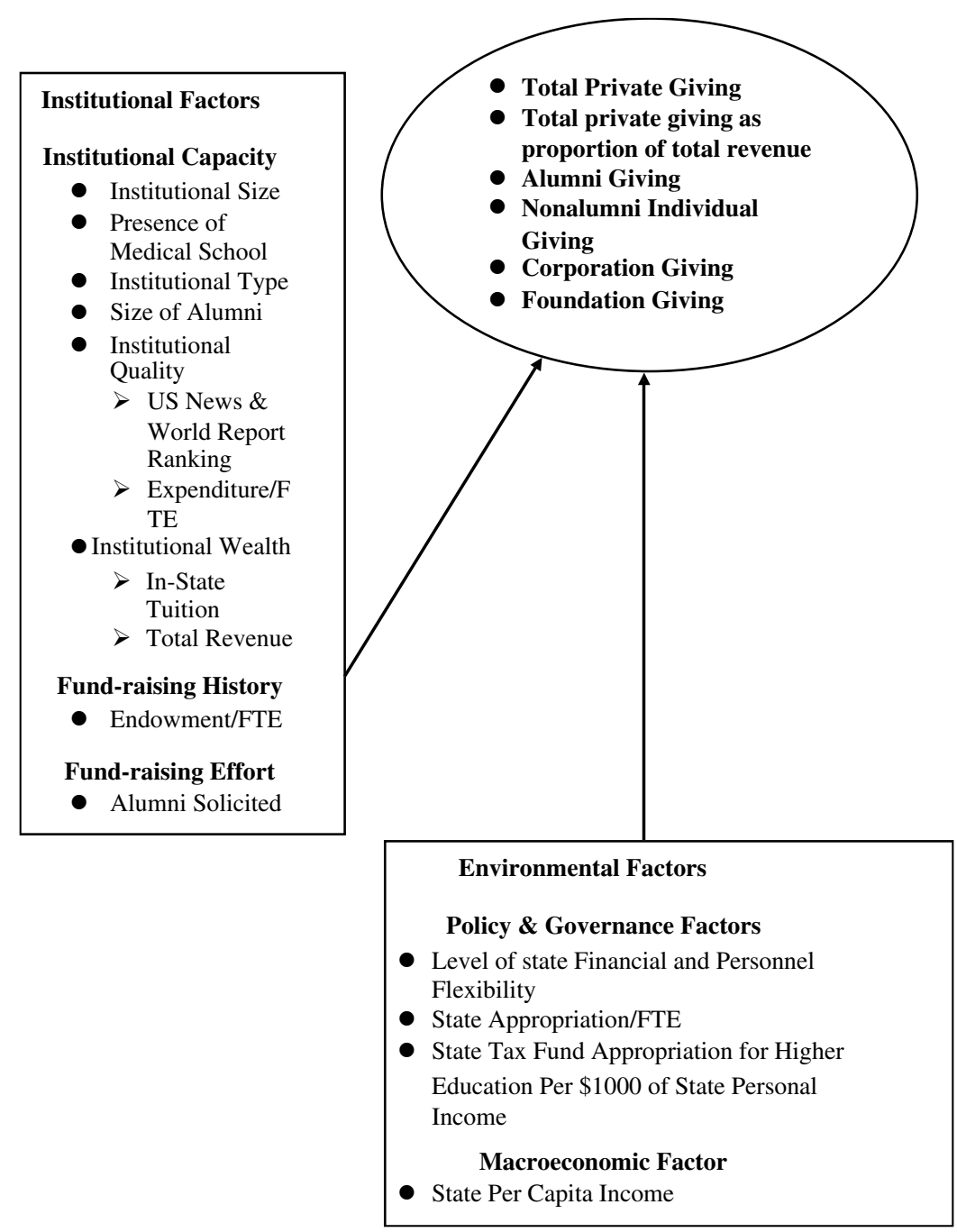

Figure 2: Independent variables that influence the dependent variables 


\section{Method}

The target population is all public four-year colleges and universities in the United States. Ordinary least squares was used to determine those variables most associated with total private giving as a proportion of total revenue as well as the level of total private giving and giving from the four sources. The basic methodological approach is to estimate the level and proportion equation of the form $\log \left(\mathrm{Gi}_{2003}\right)=f\{$ institutional capacity, fund-raising history, fund-raising effort, policy and governance factors, macroeconomic factor\}

$\mathrm{TPG}_{2003} /$ Total revenue $=f\{$ institutional capacity, fund-raising history, fundraising effort, policy and Governance factors, macroeconomic factor\}

\section{Sample}

The sample identified for this study consists of 161 public four-year colleges and universities that participated in the VSE survey and reported valid non-null data for the variables used in the study in both 1995 and 2003. Regarding the

Carnegie Classification of the universities in this sample, 90 are research universities, 68 are doctoral universities, and three are baccalaureate colleges. Public community colleges are excluded from this sample. Total private giving and sources of giving by Carnegie Classification and by US News and World Report Ranking for National Universities are presented in Table 1.

\section{Results}

Descriptive statistics, correlation matrix and regression results are presented in the tables in the
Appendix. Empirical results for the private giving regressions are presented in Table 1 in six categories: the proportion of total private giving to total revenue, total private giving, total alumni giving, total nonalumni individual giving, total corporation giving, and total foundation giving. Adjusted $R^{2}$ values for the six regression models range from 0.26 to 0.87 , suggesting the models have good explanatory power. Although some variables affect all groups of donors similarly, some affect groups of donors differently and to very different degrees. Comparison of the results across the categories provides some interesting results.

Institutional size indicated by fulltime-equivalent students was consistently significant as a predictor of giving in previous studies (e.g., Coughlin and Erekson, 1986; Leslie and Ramey, 1988), but only exerts a positive impact on alumni giving (0.26) in the present study. Being ranked highly by the US News and World Report as quartiles 1 and 2 national universities is significantly positively associated with the proportion of total private giving to total revenue $(0.28)$, total private giving (0.13), alumni giving (0.14), and corporation giving $(0.15)$. This suggests that institutional quality, or at least prestige, may help drive donor support. Doctoral/research universities under Carnegie Classification receive more total private giving and more giving from corporations and foundations, and have a higher proportion of total private giving to total revenue. This means that institutional type is an important trait to corporations and foundations and that doctoral/research universities 
Table 1: Determinants of private giving-regression results (standardized)

\begin{tabular}{|c|c|c|c|c|c|c|}
\hline Variables & $\begin{array}{l}\text { Total giving } \\
\text { as } \% \text { of } \\
\text { total revenue }\end{array}$ & $\begin{array}{l}\text { Total } \\
\text { private } \\
\text { giving }\end{array}$ & $\begin{array}{l}\text { Alumni } \\
\text { giving }\end{array}$ & $\begin{array}{l}\text { Nonalumni } \\
\text { giving }\end{array}$ & $\begin{array}{l}\text { Corporations } \\
\text { giving }\end{array}$ & $\begin{array}{l}\text { Foundations } \\
\text { giving }\end{array}$ \\
\hline \multicolumn{7}{|l|}{ Institutional capacity } \\
\hline Log of FTE enrollment (95) & 0.03 & -0.01 & $0.26^{*}$ & 0.02 & -0.02 & -0.13 \\
\hline Medical school (95) & 0.06 & 0.03 & -0.03 & 0.04 & 0.03 & 0.07 \\
\hline $\begin{array}{l}\text { Doctoral/research } \\
\text { universities (94) }\end{array}$ & $0.21 *$ & $0.17 * * *$ & 0.04 & 0.06 & $0.23 * * *$ & $0.21 * *$ \\
\hline $\begin{array}{l}\text { Change of number of } \\
\text { alumni of record (95-03) }\end{array}$ & -0.06 & 0.00 & 0.09 & 0.09 & -0.04 & -0.07 \\
\hline $\begin{array}{l}\text { US News ranking quartiles } \\
1 \text { and } 2 \text { for national } \\
\text { universities. (95) }\end{array}$ & $0.28 * *$ & 0.13 & $0.14 *$ & 0.08 & 0.15 & 0.12 \\
\hline $\begin{array}{l}\text { Change of expenditure/FTE } \\
(95-03)\end{array}$ & 0.02 & 0.04 & -0.08 & 0.02 & 0.06 & 0.03 \\
\hline In-state tuition $(95)$ & -0.13 & $-0.12 * *$ & $0.14 * *$ & -0.11 & $-0.19 * * *$ & $-0.26 * * *$ \\
\hline Log of total revenue $(95)$ & 0.00 & $0.68 * * *$ & $0.38 *$ & $0.59 * *$ & $0.64 * * *$ & $0.67 * * *$ \\
\hline \multicolumn{7}{|l|}{ Fund-raising history } \\
\hline $\begin{array}{l}\text { Change of endowment/FTE } \\
(95-02)\end{array}$ & $0.24 *$ & $0.13 *$ & $0.25 * * *$ & 0.13 & 0.01 & 0.17 \\
\hline \multicolumn{7}{|l|}{ Fund-raisig effort } \\
\hline $\begin{array}{l}\text { Change in percent of } \\
\text { alumni solicited }(95-03)\end{array}$ & 0.12 & $0.07 *$ & -0.03 & 0.07 & 0.09 & 0.03 \\
\hline \multicolumn{7}{|c|}{ Policy and governance factors } \\
\hline $\begin{array}{l}\text { High level of state financial } \\
\& \text { personnel flex }(95)\end{array}$ & -0.06 & -0.03 & -0.06 & 0.00 & 0.00 & 0.05 \\
\hline $\begin{array}{l}\text { Change of state appropriation/ } \\
\text { FTE (95-03) }\end{array}$ & -0.09 & -0.02 & $-0.19 *$ & 0.00 & -0.03 & -0.06 \\
\hline $\begin{array}{l}\text { Change of tax appropriation } \\
\text { for higher ed } \$ 1,000 \text { state } \\
\text { capital income }(95-03)\end{array}$ & -0.07 & 0.01 & $-0.20 * * *$ & -0.06 & $0.11 *$ & 0.03 \\
\hline Macroeconomic factor & & & & & & \\
\hline $\begin{array}{l}\text { Change of state per-capita } \\
\text { income }(95-03)\end{array}$ & 0.04 & 0.01 & -0.02 & 0.01 & -0.02 & $0.12 *$ \\
\hline Number of cases & 161 & 161 & 149 & 116 & 142 & 141 \\
\hline Adjusted $\mathrm{R}^{2}$ & 0.26 & 0.87 & 0.74 & 0.64 & 0.75 & 0.67 \\
\hline
\end{tabular}

$* p \leqslant=0.05$

$* * p \leqslant=0.01$

$* * * p \leqslant=0.001$

appeal to corporations and foundations more than to other types of institutions.
In-state tuition is positively associated with alumni giving (0.14), but negatively associated with 
corporation giving $(-0.19)$, foundation giving $(-0.26)$, and total private giving $(-0.12)$, suggesting the public dissatisfaction toward the rise of tuition. The effect of total revenue on total private giving and giving from all sources is very strong, confirming the hypothesis. This finding suggests that donors are influenced by a prestigerelated variable and that wealthier institutions have accumulative advantages and so receive higher levels of private giving.

Endowment growth per FTE exhibited a positive effect on the proportion of total private giving to total revenue $(0.24)$, total private giving (0.13), and alumni (0.25). It suggests that institutions with a tradition of private support have a higher proportion of total private giving to total revenue. This finding is consistent with Caboni's study, but contradicts Oster's (2001) empirical analysis of endowment growth on voluntary giving to four-year colleges and universities, which found a very recent adverse response in the giving levels to university affluence.

Institutional effort in fund raising, as proxied by change in the percent of alumni solicited, does not significantly affect alumni contribution, but it does have a positive and statistically significant effect on total private giving (0.07), although small in magnitude.

Turning to policy and governance factors, rises in state appropriation per FTE exerted a statistically significant negative influence on alumni giving with an elasticity of -0.19 , which is consistent with the finding of Leslie and Ramey (1988). Thus, an increase of 1 percent in state funding appears to lower alumni contributions by about 0.19 percent. Rises in state tax fund appropriations for higher education per $\$ 1,000$ of state personal income exhibited a negative and statistically significant effect on alumni giving $(-0.20)$, but a positive effect on corporation giving (0.11).

Lastly, the state per-capita income variable does not perform as expected. Only in the case of total foundation giving does increase in per-capita income significantly increase giving (0.12).

\section{Limitations}

This study is limited in several aspects: First of all, because of the limited number of institutions participating in the survey, there is the possibility that the data collected are not representative of all public colleges and universities in the United States.

Second, institutions that participated in the VSE survey represent a self-selected group, raising the possibility that institutions not faring well in fund raising may not generate responses for the report. The omission of these institutions may have led to a sample population not including the weakest institutions. Third, due to lack of access to relevant data, some institutional variables that may explain variations in voluntary support for colleges and universities are not included. From the existing literature, variables on fund-raising efforts (i.e. expenditure on fund raising, number of advancement professional staff) have a clear and consistent association with different levels of private giving, but information on these variables is very difficult to obtain. Lastly, by studying quantitative factors alone, it is difficult to fully explain why some institutions raise considerably more money in voluntary support than other 
institutions of the same type with roughly equivalent resources and under similar macroeconomic circumstances.

\section{Implications}

The results for the analysis provide some useful, empirically based insights into the factors propelling voluntary support of institutions. At the same time, they highlight the difficulties of fully explaining why some institutions raise considerably more money in voluntary support than other institutions of the same type with roughly equivalent resources and under similar macroeconomic circumstances by studying quantitative factors alone.

First, consistent with previous research, the results of the study suggest that institutions at the top of the institutional hierarchy enjoy accumulative advantage: doctoral/ research universities, quartiles 1 and 2 national universities by US News and World Report Ranking, and institutions with higher total revenue and increase in endowment per FTE raise more total private giving than other institutions.

Second, the negative effect of tuition on corporation, foundation, and total private giving suggests that institutions should consider the consequences of negative publicity when they raise tuition.

Third, the results also confirm that different donor groups have different motivation for donation. For example, alumni may respond well to emphasis upon institutional ranking and shortfalls in state support, while foundations will respond favorably to state economic growth. The implication for fund-raising professionals in higher education is: when dealing with different donors, different fund-raising strategies should be used and different institutional characteristics should be stressed.

\section{Future Research Directions}

First, future studies should be conducted to include less tangible factors potentially influencing private giving: the involvement of president and trustees, the leadership of the chief development officer, the quality of development staff, the organizational structure of the development offices (whether it is decentralized or centralized), and the tradition of voluntary support in an institution. It will be helpful to conduct longitudinal investigation of the factors that influence a college or university to be consistently successful at raising private support by melding results from both quantitative and qualitative data analyses.

Second, state policy in support of private fund raising has an impact on the amount of gift income received by public colleges and universities. A study of the impact of state policy on private fund raising on a state-by-state basis would provide additional insight into the dynamics of fund raising in public colleges and universities.

Third, since higher education fund raising is influenced by society attitudes toward philanthropy and the competition from other nonprofit organizations (Brewer et al., 2001), more research should be conducted on the total capacity of the economy to support fund raising and the impact of the demands of charitable giving from other areas on private giving to higher education.

Finally, it will be necessary to explore how much it costs an institution to generate private giving 
and how institutions use the additional resources accrued from private giving. Additional questions for exploration include: What differences do private gifts make on public higher education institutions that receive them? And is the pursuit of private giving cost effective for these institutions?

\section{Note}

${ }^{1}$ For the purpose of this proposal and in keeping with the literature, private giving is defined interchangeably with voluntary support, voluntary contribution, and fund raising.

\section{References}

Blau, P.M. (1968), "The hierarchy of authority in organizations," American Journal of Sociology, 73: 453-467.

Brewer, D.J., Gates, S.M. and Goldman, C.A. (2001), "In pursuit of prestige: Strategy and competition in US higher education,” Technical papers.

Brittingham, B.E. and Pezzullo, T.R. (1990), "The Campus Green: Fund Raising in Higher Education, Washington, DC: ERIC Clearinghouse on Higher Education.

Brooks, A. (1999), "The effects of public subsidies on private giving to nonprofits: Nonlinear crowding out and subsidy traps," Paper presented at the ARNOVA Conference, Arlington, VA.

Caboni, T.C. (2003), “Accumulative advantage and the voluntary support of higher education," Paper presented at the annual meeting of the American Educational Research Association, Chicago, IL.

Clotfelter, C. (1985), "Federal Tax Policy and Charitable Giving, Chicago: University of Chicago Press.

Cochi Ficano, C.K., and Cunningham, B.M. (2001), "The determinants of donative revenue from alumni of higher education: An empirical inquiry," Paper presented at the 2001 Cornell Higher Education Research Institute Annual Conference, Cornell, NY.

Cook, W.B. and Lasher, W.F. (1996), "Toward a theory of fund raising in higher education," Review of Higher Education, 20, 1, pp. 33-51.

Coughlin, C.C. and Erekson, O.H. (1986), "Determinants of state aid and voluntary support of higher education," Economics of Education Review, 5, 2, pp. 179-190.

Drachman, S.S. (1983), "Factors accounting for variations in levels of private giving to higher education in the United States," Ph.D. dissertation, University of Arizona.

Dunn Jr., J.A., Terkla, D.G. and Secakusuma, P. (1988), "Fund raising in US colleges and universities: The fifty best performances, 1979-80 through 1985-86," Paper prepared for the Twenty-Third Annual Conference of the Society for College and University Planning, Tufts University.

Duronio, M. et al. (1988), “A survey of fundraising methods: Implications for management,", Paper prepared for the annual meeting of the American Educational Research Association, New Orleans, LA.

Duronio, M.A., Loessin, B. and Borton, G.L. (1988), "A survey of fund-raising methods: Implications for management," Working paper no. 5. Paper presented at a meeting of the American Educational Research Association, April, New Orleans, L.

Feldstein, M. (1975a), "The income tax and charitable contributions: Part I-aggregate and distributional effects," National Tax Journal, 28, 1, pp. 81-99.

Feldstein, M. (1975b), “The income tax and charitable contributions: Part II-the impact on religious, education, and other organizations," National Tax Journal, 28, 2, pp. 209-226.

Gianneschi, M.E. (2004), "The effect of changes in state appropriations on voluntary giving to state supported universities," Ph.D. dissertation, University of Arizona.

Hale, J. (1987), “Altruism and Self-Interest in Elite Philanthropic Exchanges, San Diego: San Diego Community Foundation, San Diego State University.

Hearn, J.C. (2003), "Diversifying Campus Revenue Streams: Opportunities and Risks, Washington, DC: American Council on Education.

Johnstone, B. (2002), "Challenges of financial austerity: Imperatives and limitations of revenue diversification in higher education," The Welsh Journal of Education, 11, 1, pp. 19-36.

Kelly, K.S. (1991), "Fund Raising and Public Relations: A Critical Analysis, Hillsdale, NJ: Lawrence Erlbaum Associates.

Kingma, B. (1989), “An accurate measure of the crowd-out effect, income effect and price effect for charitable contributions," Journal of Political Economy,", October, pp. 1197-1207.

Kotler, P. (1972), “Marketing Management - Analysis, Planning and Control, Prentice Hall: Englewood Cliffs, NJ.

Leslie, L.L. et al. (1983), "Factors accounting for variations over time in voluntary support 
for colleges and universities," Journal of Educational Finance, 9, pp. 213-225.

Leslie, L.L. and Ramey, G. (1988), "Donor behavior and voluntary support for higher education institutions," Journal of Higher Education, 59, pp. 117-132.

Loessin, B.A., Duronio, M.A. and Borton, G.L. (1988), "Understanding fund-raising effectiveness in higher education: Laying a foundation", Final report prepared for Exxon Education Foundation.

National Center for Education Statistics. (2005), http://nces.ed.gov/.

Oster, S.M. (2001), "The effect of university endowment growth on giving: Is there evidence of crowding out?, Paper presented at the Cornell Higher Education Research Institute Conference on "Financing Higher Education in the 21st Century", Ithaca, NY.

Pickett,, W.L. (1977), "An assessment of the effectiveness of fund raising policies of private undergraduate colleges," Unpublished doctoral dissertation, University of Denver, CO.

Selingo, J. (1997), “A self-published college guide goes big-time, and educators cry foul," Chronicle of Higher Education, 44, 11, A45-A46.

Smith, C.L. and Ehrenberg, R.G. (2003), "Sources and uses of annual giving at private research universities," New Directions for Institutional Research, 119, pp. 67-79.

Steinberg, R. (1993), "Does government spending crowd out donations?," in A. Ben-Ner and B. Gui (eds.), The Nonprofit Sector is a Mixed
Economy, 99-125. Ann Arbor: University of Michigan Press.

Taussig, M. (1967), "Economic aspects of the personal income tax treatment of charitable contributions," National Tax Journal, 20, 1, pp. 1-19.

Volkwein, J.F. (1984), “Responding to financial retrenchment: Lessons from the Albany experience," Journal of Higher Education, 55, 3, pp. 389-401.

Volkwein, J.F. (1986a), "State financial control of public universities and its relationship to campus administrative elaborateness and cost," Review of Higher Education, 9, 3, pp. 267-286.

Volkwein, J.F. (1986b), "Campus autonomy and its relationship to measures of university quality," Journal of Higher Education, 57, 5, pp. $510-528$.

Volkwein, J.F. (1987), "State regulation and campus autonomy," in J.C. Smart (ed.), Higher education handbook of theory and research, Vol. 3, New York: pp. 120-154.

Volkwein, J.F. (1989), "Changes in quality among public universities," Journal of Higher Education, 60, 2, pp. 136-151.

Volkwein, J.F. and Malik, S.M. (1997), "State regulation and administrative flexibility at public universities," Research in Higher Education, 38, 1, pp. 17-42.

Woods, J.L. (1987), "Factors associated with gift income in public research and doctoral granting institutions," Unpublished doctoral dissertation,

Washington State University, Washington. 


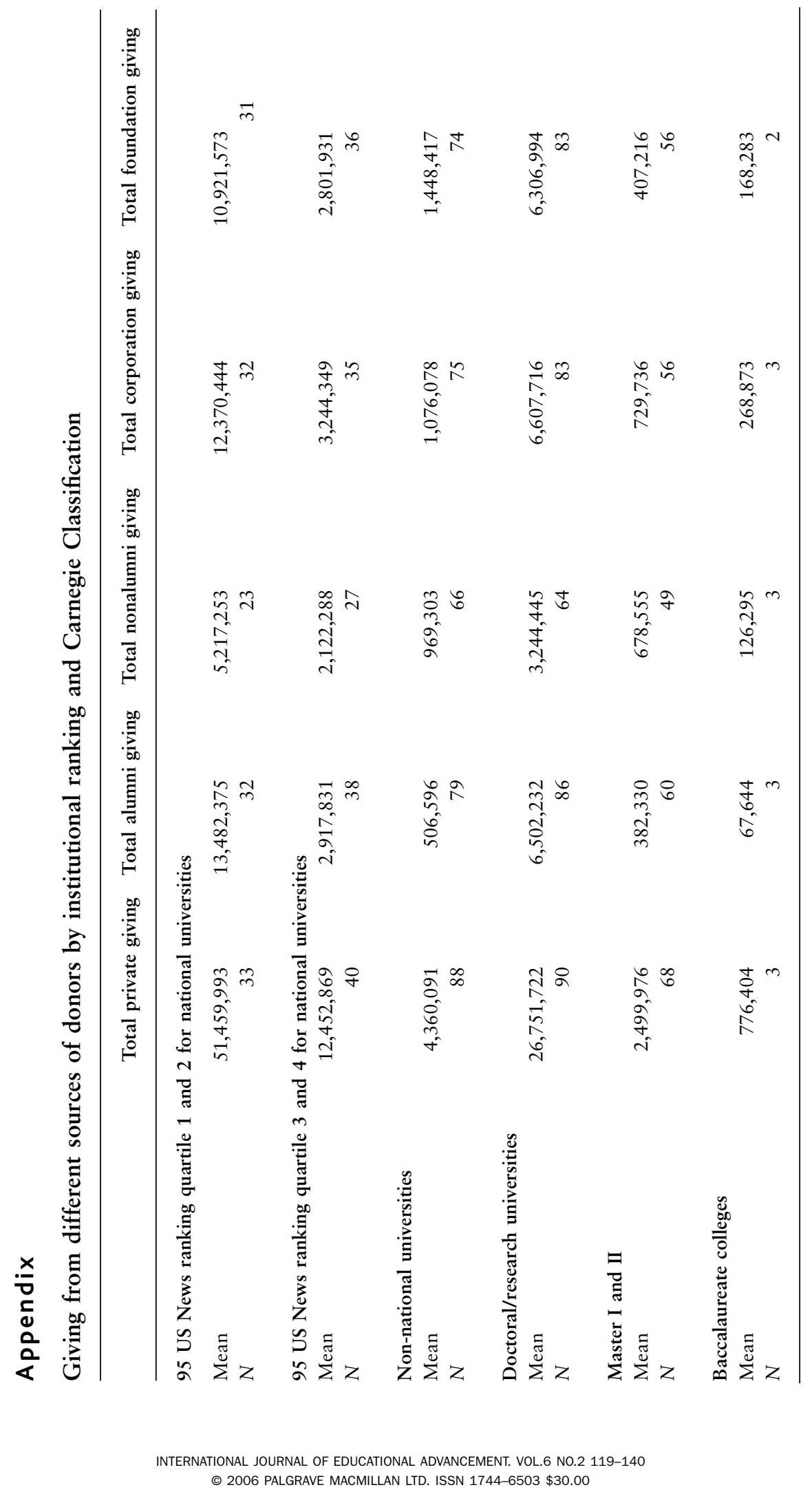




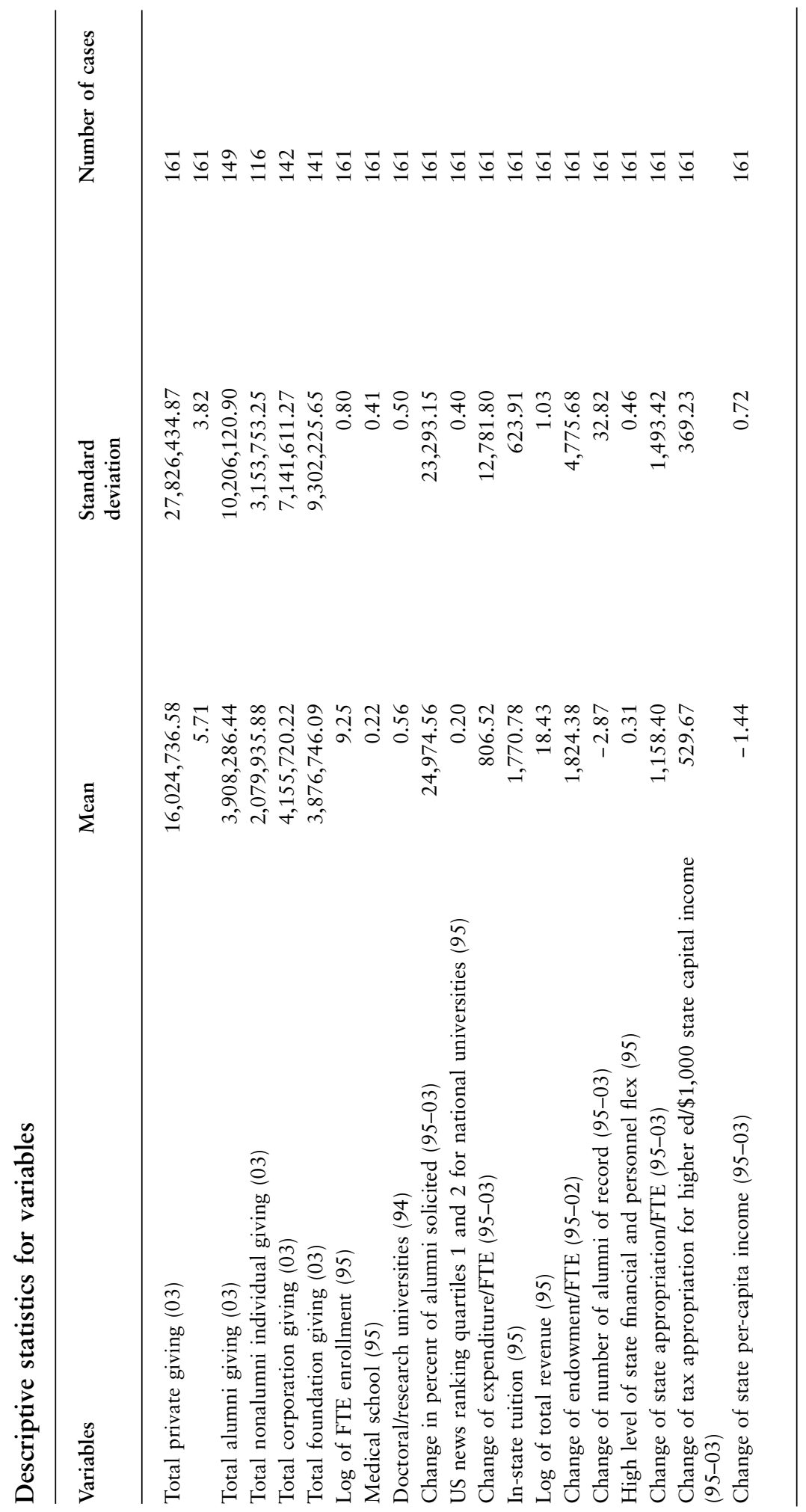




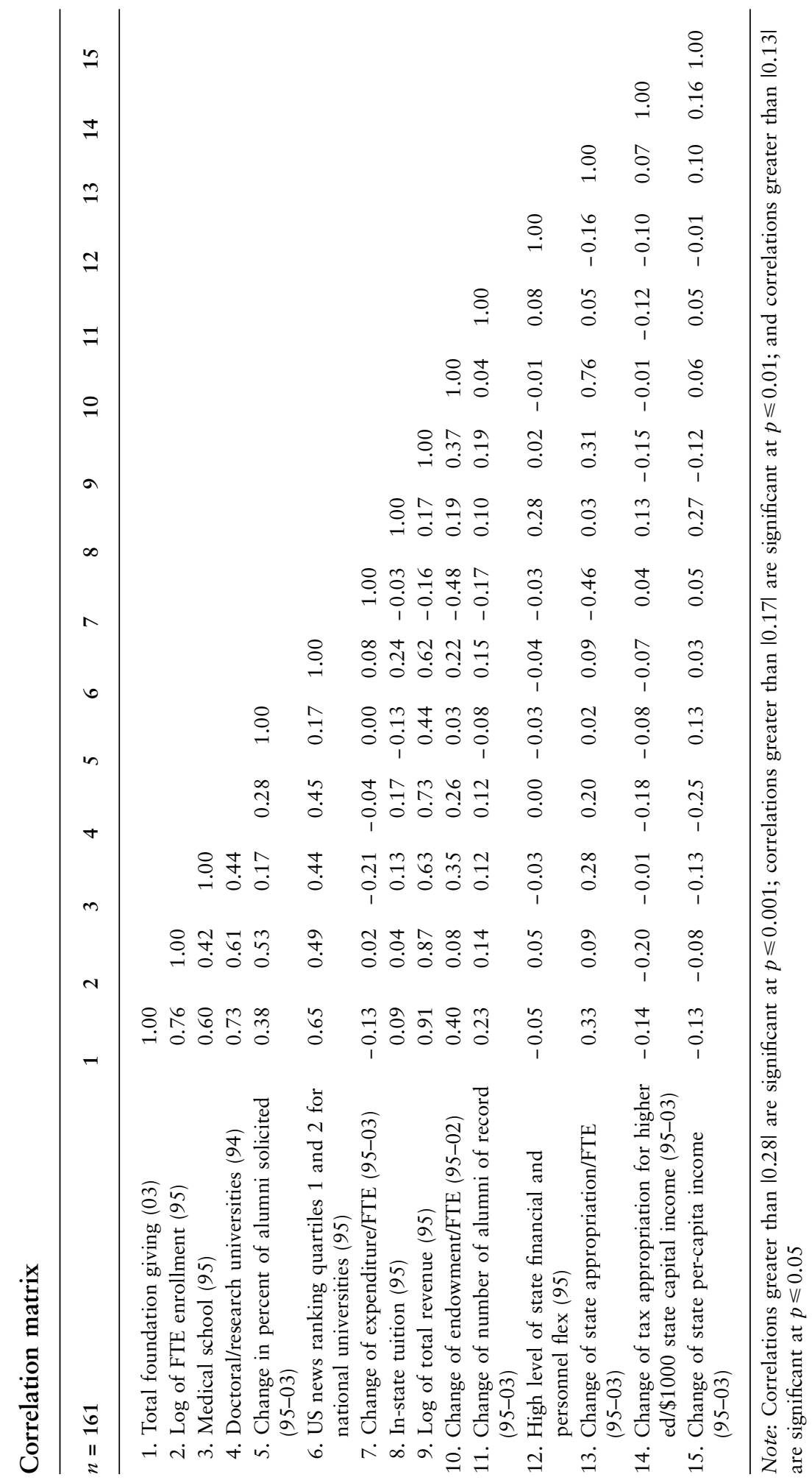

